\section{Review: infection rates do not differ for wounds cleansed with water or saline}

\section{QUESTION}

How does water compare with other solutions for cleansing wounds?

\section{REVIEW SCOPE}

Included studies compared water with other solutions for cleansing acute or chronic wounds or with no cleansing and reported objective outcome measures. Studies assessing cleansing solutions as part of dental procedures, prophylaxis, preoperative or operative procedures, and those of patients with burns or ulcers were excluded. Outcomes included wound infection and healing.

\section{REVIEW METHODS}

Medline, CINAHL, and EMBASE/Excerpta Medica (all to 2007); Cochrane Wounds Group Specialised Register; Cochrane Controlled Trials Register (Issue 3, 2007); 2 other databases; and reference lists were searched for randomised controlled trials (RCTs) or quasi-RCTs. Authors, experts, and companies were contacted. 5 RCTs and 6 quasi-RCTs (age range 2-95 y) met the selection criteria; duration of follow-up ranged from 1 to 6 weeks.

\section{MAIN RESULTS}

Meta-analysis showed that tap water reduced infections compared with saline for cleansing acute wounds (table). Individual studies showed that tap water and saline did not differ for infections or healing of chronic wounds (table); distilled water and saline, cool boiled water and saline, and distilled and cool boiled water did not differ for infections (table). No RCTs compared water with no cleansing or tap water with cool boiled water.

\section{CONCLUSION}

Infection rates do not differ for wounds cleansed with water or saline.

\section{ABSTRACTED FROM}

Fernandez R, Griffiths R. Water for wound cleansing. Cochrane Database Syst Rev 2008;(1):CD003861.

Correspondence to: Dr R Fernandez, Centre for Applied Nursing Research, Liverpool, New South Wales, Australia; ritin.fernandez@swashs.nsw.gov.au

Source of funding: no external funding.

- Clinical impact ratings: Surgery/General 7/7; Paediatrics 6/7; Surgery/Plastic 6/7; Paediatric emergency medicine 6/7; Surgery/Orthopaedics 5/7; Emergency medicine $5 / 7$

Water $v$ saline or other solutions for cleansing wounds*

\begin{tabular}{|c|c|c|c|c|c|}
\hline $\begin{array}{l}\text { Outcomes at } \\
1-6 \text { weeks }\end{array}$ & $\begin{array}{l}\text { Number of } \\
\text { trials (n) }\end{array}$ & Comparisons & $\begin{array}{l}\text { Weighted } \\
\text { event rates }\end{array}$ & RRR (95\% CI) & NNT (Cl) \\
\hline \multirow[t]{4}{*}{ Infection } & $3 \dagger(1338)$ & Tap water $v$ saline & $4.4 \%$ v $7 \%$ & $37 \%$ (1 to 60$)$ & 39 (24 to 1432 ) \\
\hline & $1 \ddagger(49)$ & Tap water $v$ saline & $0 \%$ v $12 \%$ & $84 \%(-196$ to 99$)$ & Not significant \\
\hline & $1(55)$ & Distilled water $v$ saline & $17 \%$ v $35 \%$ & $51 \%(-26$ to 81$)$ & Not significant \\
\hline & $1(51)$ & Cool boiled water $v$ saline & $29 \%$ v $35 \%$ & $17 \%(-87$ to 63$)$ & Not significant \\
\hline \multirow[t]{2}{*}{ Healing } & $1 \$(49)$ & Tap water $v$ saline & $35 \%$ v $62 \%$ & $43 \%(-7$ to 70$)$ & Not significant \\
\hline & & & & RRI (Cl) & NNH \\
\hline Infection & $1(66)$ & Distilled $v$ cool boiled water & $29 \%$ v $17 \%$ & $69 \%(-32$ to 322$)$ & Not significant \\
\hline
\end{tabular}

$\mathrm{T}$ he meta-analysis by Fernandez and Griffiths compared water with other fluids for wound cleansing and found that tap water caused fewer infections than saline. Infection rates in acute lacerations were low (3-5\%), and cost savings of switching to tap water were estimated to be $>\$ 65000000$ in the USA.

Type of delivery system was not addressed. Most studies recommend high pressure (25-35 psi) syringe irrigation. Standard water faucets deliver about 45 psi. $^{1}$ Patients who self-irrigate in a sink would not need expensive delivery devices, and fewer personnel would be exposed to open wounds. Other studies show that pulsatile lavage may harm tissues and recommend low pressure systems, such as bulb syringes or suction irrigation. ${ }^{2}$ Further study of optimum pressures and delivery devices for irrigation is needed.
In the review by Fernandez and Griffiths, solution temperature was addressed in a comparison of distilled water with cooled boiled water in open fracture wounds. As expected, infection rates were high for open fractures but did not differ between groups. In a small study, patients with lacerations preferred warm saline irrigation for comfort ${ }^{3}$; however, too few patients were included to measure infection rates

Non-sterile water irrigation may be necessary for wilderness injuries, including lacerations, which are common. ${ }^{4}$ Those participating in wilderness activities need to be prepared to care for wounds in the field. Knowing that irrigation does not require sterile saline or instruments can ease wound care until definitive medical care is available.

The review by Fernandez and Griffiths helps dispel the myth that washing with sterile solutions is required. Multicentre RCTs evaluating type of irrigation fluid, temperature, and pressure are needed.

\section{Amy A Ernst, MD, FACEP}

University of New Mexico

Albuquerque, New Mexico, USA

1. Pigman EC, Karch DB, Scott JL. Splatter during jet irrigation cleansing of a wound model: a comparison of three inexpensive devices. Ann Emerg Med 1993;22: 1563-7.

2. Draeger RW, Dahners LE. Traumatic wound debridement: a comparison of irrigation methods. J Orthop Trauma 2006:20:83-8.

3. Ernst AA, Gershoff L, Miller $P$, et al. Warmed versus room temperature saline for laceration irrigation: a randomized clinical trial. South Med J 2003;96:436-9

4. Stephens BD, Diekema DS, Klein EJ. Recreational injuries in Washington state national parks. Wilderness Environ Med 2005;16:192-7. 